\title{
Heroines and their 'moments of folly': Reflections on writing the biography of a woman composer
}

\section{SUZANNE ROBINSON}

In the book of essays titled The Art of Literary Biography, Jürgen Schlaeger recounts how a German colleague visiting the Dickens House Museum in London took particular interest in Dickens's study. There his friend watched an English schoolboy enter the room, carefully read through the words on an information sheet and then shout to his classmates: 'Dickens's chair! Dickens's chair!' Other children rushed in and began copying out the description, some of them also sketching the object itself. ${ }^{1}$ For a German, Schlaeger reports, this form of 'celebrity fetishism' was astonishing. Yet, as he explained, it stemmed from a long history of hero-worship in the Englishspeaking world. Australians, for example, also revere their heroes through relics, with public collections preserving such items as Captain James Cook's tea cup, Ned Kelly's armour, Henry Handel Richardson's ouija board and Dame Nellie Melba's shoes. ${ }^{2}$ In the case of the composer Percy Grainger, we have a whole museum housing clothing, handmade machinery, musical instruments, artworks and even his toy sailing boat.

No comparable mementos survive in the archives of the Australian-born composer Peggy Glanville-Hicks (1912-1990)—no personal library, no art collection, no wardrobe or furnishings. Nevertheless, in the space of 30 years, she has been the subject of three biographies and a bio-bibliography. ${ }^{3}$ This number in itself confirms the amount of interest in a career that spanned three continents and was intertwined with those of some of the most famous composers and virtuosos of the twentieth century. Accounts of her life justly celebrate international attention, unique artistry and triumph over adversity. When I began my own biography of Glanville-Hicks, however, I committed myself to burrowing in as many relevant archives as I could access, incorporating the voices of as many friends and colleagues as were willing or

\footnotetext{
1 Jürgen Schlaeger, 'Biography: Cult as Culture', in The Art of Literary Biography, ed. John Batchelor (Oxford: Clarendon Press, 1995), 57, doi.org/10.1093/acprof:oso/9780198182894.003.0005.

2 These are held in collections in Melbourne, of the National Museum, the State Library of Victoria, the National Trust and the Arts Centre, respectively.

3 Deborah Hayes, Peggy Glanville-Hicks: A Bio-Bibliography (Westport, CT: Greenwood Press, 1990); Wendy Beckett, Peggy Glanville-Hicks (Sydney: Collins Angus \& Robertson, 1992); James Murdoch, Peggy Glanville-Hicks: A Transposed Life (Hillsdale, NY: Pendragon Press, 2002); Suzanne Robinson, Peggy Glanville-Hicks: Composer and Critic (Urbana, IL: University of Illinois Press, 2019), doi.org/10.5406/j.ctvkjb3mb.
} 
able to contribute, paying attention to chronology, social and cultural circumstance and questioning what part gender played in her career. In sifting through several thousand letters, I discovered wit, humour, passion and stoicism, and that, despite many setbacks, the composer had very artfully conjured for herself a life that matched her concept of the life of a significant creative artist. At times though I also encountered mythmaking and storytelling-some of it stretching plausibilityand opinions or outbursts that were disagreeable enough to shock or horrify me. How does a biographer respond, as Dea Birkett and Julie Wheelwright did, to the involuntary cry of 'How could she'?' I was forced to decide how to represent unedifying details (if at all) and whether or not to intervene in the narrative by offering my own response. Certainly, the 'new' biography encourages frankness. According to Hermione Lee, writing about 'fallen idols':

Though contemporary biography has not always been artful and selective, it does pay a debt to modernist discussions and practice of the genre, in its belief in truth-telling, humour, and realism, its emphasis on childhood and sexuality, its explorations of inner lives as much as public achievements, and its reluctance (with a few notorious exceptions) to moralize, take sides, or cast blame. ${ }^{5}$

These are challenging aims. For the feminist biographer to conform to such precepts as well as to write in the wake of outstanding musicologist-biographers who have single-handedly recovered the lives of women composer-heroines of the likes of Francesca Caccini (1587-1640), Clara Schumann (1819-1896) and Ruth Crawford Seeger (1901-1953), the troublesome question is whether the exposure of a woman subject's imperfections undermines perceptions of her status as a composer. ${ }^{6}$ Claire Tomalin in her biography of Dickens committed herself to documenting his failings 'with an unblinking eye', but is that kind of commitment prudent when writing about a figure whose reputation is still to be fully established? ${ }^{7}$

\section{On heroes and heroines}

Biographies tend to be written about heroes and heroines (but mostly about heroes). Carlyle argued in a volume of lectures titled On Heroes, Hero-Worship and the Heroic in History: 'We cannot look, however imperfectly, upon a great man, without gaining something by him. He is the living light-fountain, which it is good

\footnotetext{
4 Dea Birkett and Julie Wheelwright, “How Could She?”: Unpalatable Facts and Feminists' Heroines', Gender \& History 2, No. 1 (Spring 1990): 49, doi.org/10.1111/j.1468-0424.1990.tb00078.x.

5 Hermione Lee, Biography: A Very Short Introduction (Oxford: Oxford University Press, 2009), 91.

6 Suzanne G. Cusick, Francesca Caccini at the Medici Court: Music and the Circulation of Power (Chicago: University of Chicago Press, 2009), doi.org/10.7208/chicago/9780226338101.001.0001; Nancy B. Reich, Clara Schumann, the Artist and the Woman (Ithaca, NY: Cornell University Press, 1985); Judith Tick, Ruth Crawford Seeger: A Composer's Search for American Music (New York: Oxford University Press, 1997).

7 See the blurb for Tomalin's biography, Charles Dickens: A Life (New York: Penguin, 2011), available, for example, from: www.worldcat.org/title/charles-dickens-a-life/oclc/707969079.
} 
and pleasant to be near. ${ }^{8}$ He graded his heroes into types, such as poets and kings, and divined a life pattern, beginning in poverty and enduring through piety, as an inspiration to us all. While the tradition of writing about Great Men was repudiated in the early twentieth century by Lytton Strachey and others, and then 'trashed' by the poststructuralists, it lingers. ${ }^{9}$ Leon Edel has defined biography as 'the life story of a man or woman whose uniqueness makes him or her a valid biographical subject'. ${ }^{10}$ The most highly reputed contemporary biographers in English are those linked to indisputably great Anglo-Saxon men or women writers: Peter Ackroyd to Dickens and T.S. Eliot, Victoria Glendinning to Vita Sackville-West, Hermione Lee to Virginia Woolf and Claire Tomalin to Jane Austen. Several of their books are monumental achievements_-Lee's biography of Woolf comes close to 900 pagesand in their level of detail, their stupendous marshalling of documentation, fact and event, as well as their perceptiveness, they may not be superseded for a generation. Lee's publisher assures us that this is a biography worthy of 'one of our century's most brilliant and mercurial writers' and that, conversely, Lee has had the courage to 'leave all of [Woolf's] complexities and contradictions intact'. ${ }^{11}$

In my own field of music history, composers tend to be portrayed as Romantic heroes. Attitudes to biography have been shaped by landmark accounts of the lives of the great German composers: Otto Jahn's W.A. Mozart (1856-59, 1867), Alexander Wheelock Thayer's Life of Beethoven (1866-79) and Philipp Spitta's Johann Sebastian Bach (1873-80). As Jolanta Pekacz points out in an essay on 'musical biography and its discontents', nineteenth-century biographies of composers such as these have tended towards hagiography. ${ }^{12}$ Our more recent zeal for uncovering the 'truth' and an assumption that new-generation scholarship is infallibly 'truthful' have led to numerous encyclopaedic revisions of ageing biographies. For all their erudition and masterful archaeology, many of these continue to uphold the ideology of the hero. ${ }^{13}$ Alan Walker's three-volume biography of Franz Liszt, completed in 1997, devotes a section to the demolition of the possibility that Liszt fathered illegitimate children, the author clearly exasperated with the rumour mill's tendency 'to saddle

8 Thomas Carlyle, 'Lecture I. The Hero as Divinity. Odin. Paganism: Scandinavian Mythology', in On Heroes, Hero-Worship and the Heroic in History, (1840), Project Gutenberg, www.gutenberg.org/files/1091/1091-h/1091-h. htm.

9 Nigel Hamilton, Biography: A Brief History (Cambridge, MA: Harvard University Press, 2007), 209, doi.org/ $10.4159 / 9780674038226$.

10 Leon Edel, 'Biography and the Sexual Revolution: Why Curiosity Is No Longer Vulgar', New York Times Book Review, 24 November 1985, 13.

11 Hermione Lee, Virginia Woolf (London: Chatto \& Windus, 1996).

12 As, for example, in her discussion of Schubert. See Jolanta T. Pekacz, 'Memory, History and Meaning: Musical Biography and Its Discontents', Journal of Musicological Research 23 (2004): 55, doi.org/10.1080/01411890490 276990.

13 Christopher Wiley, in his $\mathrm{PhD}$ thesis on musical biography, notes that 'musicology presently suffers from a dearth of critical-historical research in which biography ... is given extended comparative investigation'. See Christopher Wiley, Re-Writing Composers' Lives: Critical Historiography and Musical Biography, PhD thesis (Royal Holloway, University of London, 2004), 10. 
great men with illicit offspring'. ${ }^{14}$ Christoph Wolff's biography of Bach (2000), while at 600 pages a document of substantial scholarship, equates the greatness of the music with the greatness of the life, so that Bach becomes a pillar of the church, an exemplary entrepreneur, an intellectual who ranked with Newton, whose body of writings, if only they had not been lost, would testify to his superior intellect. ${ }^{15}$ Biographers-and their readers_-want to continue to worship their heroes in music. So, when Paul Kildea in his 600-page biography of Benjamin Britten uncovered evidence to suggest that Britten's fatal heart condition was caused by syphilis - a disease so unmentionable his doctors never divulged it — the biographer faced a storm of protest. ${ }^{16}$

Biographers of women musicians also search for heroine subjects. Becca Anderson's book profiling 200 'boundary breakers, freedom fighters, sheroes and female firsts' names women painters, writers, dancers and singer-songwriters. ${ }^{17}$ Women composers have also been 'boundary breakers', though not always in ways that are readily recognisable. Susan McClary in an article on the intersections of musicology and feminism frames the dilemma of defining the woman composer as a heroine. Do we admire their works, she asks, 'simply because they were composed by women?'. ${ }^{18}$ Or can we find ways to approach them more critically? Should we elaborate on the factors that explain why the music might be of inferior quality, or can we claim greatness despite limited outputs and the predominance of domestic genres? Pekacz is sceptical that women composers can measure up, accusing biographers of women composers of a lack of scholarly rigour. On the basis of the biographies that have advocated for the 'greatness' of Felix Mendelssohn's sister, Fanny Hensel, Pekacz argues that

feminist biographers manufacture stories of suppressed female geniuses in a way that demonstrates the unreflective adherence of these authors to predetermined explanatory schemes and political agenda, to familiar nineteenth-century plots of heroic and masculine biography, as well as their disregard for historical context, let alone evidence. ${ }^{19}$

14 Alan Walker, Franz Liszt: The Virtuoso Years 1811-1847, rev. edn (Ithaca, NY: Cornell University Press, 1987), 25.

15 See the discussion of Wolff's book in Pekacz, 'Memory, History and Meaning', 61-62.

16 Paul Kildea, Benjamin Britten: A Life in the Twentieth Century (London: Allen Lane, 2013). On the subject of Britten's supposed syphilis, see, for example, Charlotte Higgins, 'Benjamin Britten Syphilis "Extremely Unlikely", Says Cardiologist', The Guardian, 23 January 2013, www.theguardian.com/music/2013/jan/22/benjamin-brittensyphilis-condition-unlikely-cardiologist.

17 Becca Anderson, The Book of Awesome Women: Boundary Breakers, Freedom Fighters, Sheroes, and Female Firsts (Coral Gables, FL: Mango, 2017).

18 Susan McClary, 'Reshaping a Discipline: Musicology and Feminism in the 1990s', Feminist Studies 19, No. 2 (Summer 1993): 405-6, doi.org/10.2307/3178376.

19 Pekacz, 'Memory, History and Meaning', 45. They are: Carol Lynelle Quin, Fanny Mendelssohn Hensel: Her Contributions to Nineteenth-Century Musical Life (Ann Arbor, MI: UMI Research Press, c. 1981); Victoria Ressmeyer Sirota, The Life and Works of Fanny Mendelssohn Hensel (Ann Arbor, MI: UMI Research Press, 1981); Françoise Tillard, Fanny Mendelssohn (Portland, Ore.: Amadeus, 1996); and Gloria Kamen, Hidden Music: The Life of Fanny Mendelssohn (New York: Simon \& Schuster, 1996). 
No-one would deny a biographer's subjectivity, which in part explains why four biographies of Hensel have been published since 1981. But feminists attempting to promote the cause of Fanny Hensel have alleged that her talents were callously suppressed by her father and brother, and the simplistic distillation of this claim (as seen, for example, in the headline in The Washington Post in 2017 that alleged that 'a Mendelssohn masterpiece was really his sister's') has led to a backlash that makes the recuperative project far more onerous. ${ }^{20}$ According to Marian Wilson Kimber:

[T]he story of Fanny's 'suppression' is neither accurate, new, nor feminist in its origins or construction ... Centering Hensel's biography on her brother's comments rather than on her eventual publication of her music both denies her the power she did have in life and oversimplifies the historical situation for women composers, replacing the manifold issues surrounding gender and class with a single male villain. ${ }^{21}$

In light of Kimber's none-too-subtle attack on feminist scholars including Marcia J. Citron who have perpetuated the suppression story, ${ }^{22}$ declarations of the 'greatness' of a woman composer require more stringent tests. ${ }^{23}$

Interestingly, Edel assumes that the biographer's subject is always a personal hero or heroine regardless of public opinion. ${ }^{24}$ In the case of a composer-as for a writer, playwright or painter-biographers usually admit to liking their subject's works, and it is admiration for the works themselves that more often than not compels their readers. This means, and Edel concedes, that biographers will inevitably struggle against 'their own resistance to discovering unpleasant truths, and what their secret selves are up to in shaping the materials. ${ }^{25}$ How, then, can the biographer balance between plots that authorise greatness and the revelation of personal foibles or errors of judgement that come with in-depth archival research and the demand for impartiality? Unpleasant opinions can be voiced by others. Selfish or egotistical acts can be dismissed as 'moments of folly' or excused by myriad emotional, physical,

20 Derek Hawkins, 'A Mendelssohn Masterpiece Was Really His Sister's. After 188 Years, It Premiered under Her Name', The Washington Post, 9 March 2017, www.washingtonpost.com/news/morning-mix/ wp/2017/03/09/a-mendelssohn-masterpiece-was-really-his-sisters-after-188-years-it-premiered-under-her-name/? noredirect $=$ on\&utm_term $=.3 \mathrm{~d} 7224 \mathrm{faea} 0 \mathrm{c}$.

21 Marian Wilson Kimber, 'The "Suppression” of Fanny Mendelssohn: Rethinking Feminist Biography', 19th-Century Music 25, No. 2 (2002): 128, doi.org/10.1525/ncm.2002.26.2.113.

22 Among Citron's responses are Marcia J. Citron, 'Feminist Waves and Classical Music: Pedagogy, Performance, Research', Women and Music 8 (2004): 47-60, doi.org/10.1353/wam.2004.0004; Marcia J. Citron, 'A Bi-Centennial Reflection: Twenty-Five Years with Fanny Hensel', Nineteenth-Century Music Review 4, No. 2 (2007): 7-20, doi.org/ 10.1017/S1479409800000859; Marcia J. Citron, 'Coda: A Reply to Marian Wilson Kimber', Nineteenth-Century Music Review 6, No. 2 (2009): 175-76, doi.org/10.1017/S1479409800003281.

23 The most noteworthy in the pantheon of woman composers is Hildegard of Bingen (1098-1179), the subject of a spate of books and recordings in the 1990s and a recent biography by Honey Meconi, but even there some scholars dispute whether Hildegard actually wrote the music credited to her. See Richard Witts, 'How to Make a Saint: On Interpreting Hildegard of Bingen', Early Music 26, No. 3 (1998): 479-85, doi.org/10.1093/earlyj/XXVI.3.478.

24 Leon Edel, Writing Lives: Principia Biographica (New York: W.W. Norton, 1984), 67.

25 Edel, Writing Lives, 67. 
social or cultural forces as the price they paid for being rebels. ${ }^{26}$ It would be easy to skip over anomalies, ignore them or, more deviously, admit them without comment. Hermione Lee, for example, reported in her biography of Virginia Woolf that Woolf's remarks about Jews and 'the lower classes' were offensive but omitted to state who was offended, leaving the reader to wonder how much or whether her Jewish husband, Leonard Woolf, was indeed offended. ${ }^{27}$ Perhaps the biographer herself took offence. The conundrums themselves elucidate the complexities of identity. Sara Alpern and her fellow writers in The Challenge of Feminist Biography urge biographers of women to adopt an active rather than neutral voice and to allow for contradictions and uncertainties. ${ }^{28}$ In my own experience of researching the life of a woman composer, I was repeatedly reminded of these injunctions.

\section{Peggy Glanville-Hicks as heroine}

The first book-length biography of Peggy Glanville-Hicks (1912-90) was published in 1992, two years after her death. Written by Wendy Beckett, a young Sydney journalist and playwright, it is based on interviews corrupted by Glanville-Hicks's poor memory (the result of illness and old age) and her lifelong tendency to exaggerate. ${ }^{29}$ According to Beckett, Glanville-Hicks

would create or recreate the dialogue and character for the telling ... she teased me theatrically, never clearly distinguishing authenticity of fact ... Together, as composer and playwright, we heard the most extraordinary stories, some real, some of Peggy's making. ${ }^{30}$

Unfortunately, this book has reified innumerable myths that will prove difficult to shift. It portrays Peggy the schoolgirl as a loner:

Peggy was single-minded about music and never doubted her destiny. She wrote a piece of music [at school] which she described as being a 'completely unconscious act'. As if driven by some inner compulsion to write music, and imbued with a belief in herself as a composer, Peggy felt a sense of predestination. ${ }^{31}$

In this narrative, the gifted young composer leaves the colonial wasteland for civilisation, meets and marries the man she alone recognises as a genius and establishes the two of them in a bohemian loft. When war intervenes, they successfully escape, first by visiting Australia and then by emigrating to New York- the centre of the

26 Birkett and Wheelwright, "“How Could She?”, 50.

27 Lee, Virginia Woolf, 314.

28 Sara Alpern, Joyce Antler, Elisabeth Israels Perry and Ingrid Winther Scobie, 'Introduction', in The Challenge of Feminist Biography: Writing the Lives of Modern American Women (Urbana, IL: University of Illinois Press, 1992), 11.

29 See Suzanne Robinson, 'Telling a Life-Or Lies? On the Auto/Biography of Peggy Glanville-Hicks', Australasian Music Research 4 (1999): 95-112.

30 Beckett, Peggy Glanville-Hicks, 2.

31 Beckett, Peggy Glanville-Hicks, 9. 
universe'. ${ }^{32}$ There the composer is so impressed with her boss, the chief critic at the highly esteemed New York Herald Tribune, that she quickly learns to emulate him, becoming known for 'bold responses' that were 'almost as notable as her reviews'. ${ }^{33}$ She falls in love with a promising American composer, whose 'eccentricity, intellect and humour went unmatched'. ${ }^{34}$ Meanwhile, her 'composition work continued to grow ... and the rewards began to pour in'. ${ }^{35}$ In mid-century New York City concerts, 'her name recurred in almost every program'. ${ }^{36}$

This version of the life divulges the subject's own opinion of herself and her gifts, and could just as well fit the story of a Great Man were it not for the succession of relationships in which Glanville-Hicks plays muse or handmaiden to just such a Great Man, as a kind of Alma Mahler-like figure intoxicated by the scent of masculine genius. ${ }^{37}$ Yet with a little more perspective, Glanville-Hicks undeniably warrants treatment as a successful woman composer: she was the first American woman to receive a commission for an opera and, in her time, was one of very few influential women music critics in the country. Her output includes operas, ballets, scores for films, chamber music and a frequently performed and recorded harp sonata. To a young and aspiring American woman composer, she may well have seemed a heroine, and when in old age Glanville-Hicks returned to Australia, she became a mentor to a generation of younger colleagues.

\section{Glanville-Hicks and the 'impulse to self-invention'38}

Like all modern musicological biographers, I embarked on a biography of Glanville-Hicks with the intention of debunking myths and restoring 'truth'. But what happens when uncovering the facts and digging ever deeper lead us to see a heroine in a darker and more unattractive light? Carolyn Heilbrun pities biographers of the great women of the past who

have had to struggle with the inevitable conflict between the destiny of being unambiguously woman and the woman subject's palpable desire, or fate, to be something else. Except when writing about queens, biographers of women have not therefore been at ease with their subjects - and even with queens, like Elizabeth I of England, there has been a tendency to see them as somewhat abnormal, monstrous. ${ }^{39}$

\footnotetext{
32 Beckett, Peggy Glanville-Hicks, 70.

33 Beckett, Peggy Glanville-Hicks, 76.

34 Beckett, Peggy Glanville-Hicks, 108.

35 Beckett, Peggy Glanville-Hicks, 108.

36 Beckett, Peggy Glanville-Hicks, 101.

37 On the 'muse paradigm' that has infected biographies of male as well as female composers, see Wiley, Re-Writing Composers' Lives, 232-51.

38 Paul John Eakin, Fictions in Autobiography: Studies in Self-Invention (Princeton, NJ: Princeton University Press, 2014), 7.

39 Carolyn G. Heilbrun, Writing a Woman's Life (London: Women’s Press, 1989), 21.
} 
It is inevitable, Heilbrun suggests, that outstanding women of the past would be, in some way, deviant; they would not have succeeded otherwise.

By the time she reached her seventies, Glanville-Hicks was a notoriously eccentric figure who told outrageous stories, treated eminent composers like flunkeys and once kicked a well-known American composer out of her Sydney home for burning the toast. One of her closest friends, James Murdoch, a writer and music administrator who admired her 'beautiful' music and 'insouciant humour', decided in the last few years of her life to write an 'authorised' biography. ${ }^{40}$ By then, his subject's mythmaking habit had led to the development of what he called 'her repertory of oft-repeated, polished and revisionist stories'. ${ }^{41}$ So cagey was she about her past that Murdoch was forced to incorporate some of those stories alongside his own observations and suppositions. Based on his knowledge of her in her sixties and seventies (in the 1970s and 1980s), he alleged, for example, that in the early 1940s, when she was barely 30 and photos illustrated her taste and elegance, 'her clothes were a concoction of fakery with a few pieces of family trinkets used as diversion'. ${ }^{42}$ Although her fondness for capes dated from her residence in Greece in the 1960s (and perhaps earlier), Murdoch claimed her outfits were 'all disguised by a good cape or shawl and a toss of the shoulder'. ${ }^{43}$ Because he was both friend and biographer, Murdoch allowed himself a licence to fill in the gaps. He awarded her powers she never had, depicting her nurturing the talents of her famous male friends and then dropping them and, after a hiatus in the early 1940s, composing with such ease that 'music began to pour out of her'. ${ }^{44}$ When faced with the memory lapses of GlanvilleHicks's friend and former lover Paul Bowles_-with whom she had corresponded for more than 40 years - the biographer himself supplied the necessary details. Murdoch later wrote:

[B]y filling in these lacunae ... I helped him [Bowles] focus on Peggy the composer, Peggy the writer, Peggy the vital personality, where previously he had been content to think of her only as a reflection of himself. ${ }^{45}$

Reading between the lines, though, it was hard to sustain the idealist's view. By its end, their friendship had become burdensome and Murdoch's own ambivalence can be sensed when he refers to his subject as 'an old and lonely lady'. ${ }^{46}$

Aware of the myths and distortions surrounding the composer, my own biographical research drew on sources including published interviews, letters and annual appointment diaries. Even there, however, it was difficult to separate fact from

40 Murdoch, Peggy Glanville-Hicks, 272.

41 Murdoch, Peggy Glanville-Hicks, 253.

42 Murdoch, Peggy Glanville-Hicks, 40.

43 Murdoch, Peggy Glanville-Hicks, 40.

44 Murdoch, Peggy Glanville-Hicks, 41, 46.

45 Murdoch, Peggy Glanville-Hicks, 51.

46 Murdoch, Peggy Glanville-Hicks, 253. 
fiction, or at least creative embroidery. In an interview with an Australian journalist in London in 1947, for example, Glanville-Hicks referred to her husband and their home when by then they had separated. ${ }^{47}$ She even felt the necessity to boast to her closest friends. In New York in the 1950s, when she was in her forties and at the apex of her career as a composer and music critic, she attempted to puff up her credentials as an opera composer by confiding to the chief music librarian of the New York Public Library that, as a teenager, she had been involved in every aspect of mounting seven productions of modern opera in Melbourne and then another dozen while a student at the Royal College of Music in London. ${ }^{48}$ In the case of the early seven productions, she was referring not to some august opera organisation, but to productions by the students of the boutique Melba Conservatorium under its director British-born composer Fritz Hart. To reach this number of operas, she had to be counting double bills and operas by Mozart and Donizetti; her part was likely to have been menial at best. ${ }^{49}$ Even if these examples show her playfulness with the details of her past, she was also capable of telling blatant lies, once writing to her closest male friend, the dancer and choreographer John Butler, that she had lived for two years with her composition teacher Ralph Vaughan Williams and his wife, Adeline, in their house in Dorking, south of London. ${ }^{50}$ While the story provides evidence of her admiration and reverence for her teacher, her diaries show that her visit in fact lasted only a few days. ${ }^{51}$

\section{Glanville-Hicks playing with the truth}

One of the most shocking of the fictions that Glanville-Hicks contrived relates to the Sonata for Piano and Percussion she composed in 1951 as a sign of her identification with major American avant-garde composers (such as George Antheil, Henry Cowell and John Cage-all now known and canonised for their landmark percussion works of the 1920s and 1930s). There is no question that Glanville-Hicks's work was a novel concept; although it may have been encouraged by these men and was a homage to the Sonata for Two Pianos and Percussion (1937) by the Hungarian composer Béla Bartók, the performance of such a work in Manhattan was so novel that Glanville-Hicks devised the premiere herself,

47 Elizabeth Auld, 'This Melbourne Girl is Creating a Fine Musical Career Abroad', The Herald, [Melbourne], 31 July $1947,25$.

48 Glanville-Hicks, letter to Carleton Sprague Smith, 3 February [1957?], Box 11, Papers of Glanville-Hicks, MLMSS 6394, State Library of New South Wales, Sydney [hereinafter PGH-SLNSW].

49 The operas she is counting may have begun with Mozart's Cosi fan tutte in 1928, the double bill of Donizetti's The Daughter of the Regiment and Fritz Hart's The Woman Who Laughed at Faery in 1929, the double bill of Hart's Ruth and Naomi and Mozart's Il seraglio in 1930 and the double bill of Hart's Pierrette and St George and the Dragon in 1931. Glanville-Hicks left Melbourne for London in June 1932.

50 Glanville-Hicks to John Butler, 5 September [1958], Box 7, PGH-SLNSW.

51 Diary for 1937, Series 3, Glanville-Hicks Papers, MS 9083, National Library of Australia, Canberra [hereinafter PGH-NLA]. 
planning an extraordinary 12 hours of rehearsals and scouring the island for just the right sort of drums. Held at the Museum of Modern Art in 1952, the concert included a performance of Cowell's Ostinato Pianissimo for rice bowls, drums, gongs and piano (requiring the pianist to play directly on the strings of the piano), and a suite by Elliott Carter played on four timpani. She waged a publicity campaign promoting both percussion and the concert, persuading a colleague at the New York Herald Tribune to announce that 'the percussion ensemble itself is quite able to create a self-sufficient and autonomous organic structure using the various tonal and sonority possibilities of those instruments. ${ }^{52}$ In the notes to the recording of her work, Glanville-Hicks argued:

Percussion is no new phase in American music, for the orchestration of rhythm has been offered in rice bowls and brake drums, road drills, typewriters and aeroplane propellers through the years ... My concept, however, of percussion [is] not to escape from pitch and tonality—but to return with music toward these ... and my graded tonal percussion unit of normal symphonic instruments appearing in their own right as a chamber ensemble had a marked effect, then and later on, on both composers and audience..$^{53}$

Critics who attended the concert were not so convinced. One felt he was imprisoned inside a giant mechanical clock and another declared the ideas in her work were 'not out of Miss Glanville-Hicks' top drawer', belonging too obviously to the 'Bedouins-in-the-desert and rush-hour-in-Hong-Kong traditions' ${ }^{54}$ She must have been pleased, however, when the chairman of the museum's auditorium committee described the concert as the success of the season. ${ }^{55}$

Two months later, Glanville-Hicks arrived in Melbourne to visit her family. To reporters, including one from the Melbourne Age, she commented on the sonata, explaining that she had taken themes in the first and last movements from the music of the 'Watuzzi' Africans, having heard it on recordings held at the Office of War Information (OWI) (where it was Cowell who amassed the collection). She may have heard recordings in the OWI archives but this was almost certainly not the source of her themes. After discovering that the 'Watuzzi' (Watutsi or Watusi) belong to the Tutsi tribe of Burundi, the Democratic Republic of Congo and Rwanda, I received a tip-off from a friend that led me to the MGM movie of Rider Haggard's King Solomon's Mines. ${ }^{56}$ Released in 1950 (the year before Sonata for Piano and Percussion was composed), it contains spectacular footage of African scenery and wildlife-the result of MGM sending its cast and crew on a 23,000-kilometre safari. There is

52 Jay S. Harrison, 'The Musical Scene', New York Herald Tribune, 4 May 1952, 4-5.

53 Glanville-Hicks, Notes to the recording of Sonata for Piano and Percussion, Columbia Records, ML 4990 (1955).

54 C.S. [Cecil Smith], 'Music for Percussion: Museum of Modern Art, May 6', Musical America 72, No. 7

(May 1952): 27.

55 Gertrud Mellon, letter to Glanville-Hicks, 8 May 1952, Box 12, PGH-SLNSW.

56 The tip-off was from Joel Crotty, whose advice has been invaluable to my research on Glanville-Hicks. 
virtually no Western music in the film, all of the soundtrack being made and sung by tribesmen. Surprisingly, Glanville-Hicks took from this movie not one but three themes, two of them becoming the two principal themes of the first movement of her sonata. This discovery at least provides evidence of the authenticity of her source and of the truthfulness of her claim of its ethnicity. The movement she devises out of these themes is rigidly constructed in repeating four-bar units, as it is in the original. But something that in non-Western music is associated with a repetitive task (trekking across the desert) appears predictable in a Western artwork when it is reduced in complexity to a simple theme on the piano. Should we read the work as evidence of originality or even as a portend of composers' attempts to synthesise Western and non-Western sources? Unfortunately, in the twenty-first century, conditioned as we are by the scruples of ethnography, the transition from African vocal polyphony to the sound of an instrument whose heyday was in the late nineteenth century seems not just pedestrian but a desecration of the original.

For a composer to withhold information about the sources of her musical ideas is not perhaps so unusual, even less so in the postmodern era when our lives are saturated with sound. But to be deliberately misleading about her sources is another matter, particularly when she was attempting to link her work to ethnomusicological research and, by association, to Cowell's immense knowledge of 'primitive' cultures. What, then, does the lie convey? It tells me how much Glanville-Hicks desperately wanted to be part of both the percussion and the Orientalising movements then in vogue among her New York friends, how much she valued authenticity and how much she wanted to be seen as an innovator like them. It also suggests she had little time to compose and that the formal advance of the work-its mosaic structurewas developed not because the top drawer was empty but because she had no time to even open it. Perhaps most significantly, the 'secret' source of this work conveys that she went to the movies often enough to notate the melodies she heard and that her Orientalising tendencies were encouraged if not formed by popular culture. It reminds me that moviegoing was an integral part of her friendships with women, something that would become more obvious once she abandoned composing and needed the company. But can I make excuses for her? Should I treat this as a 'moment of folly' and so undermine the significance of her propagandising on behalf of the leading American composers writing for percussion, or overlook it as unrepresentative and unworthy? ${ }^{57}$

57 Birkett and Wheelwright (“'How Could She?", 50) refer to the temptation to regard unpalatable facts as 'moments of folly'. 


\section{Glanville-Hicks playing with identity}

One other equally disturbing incident in Glanville-Hicks's life defies easy rationalisations. In 1960, after almost 20 years of living and working in Manhattan, she immigrated to Greece. Although in New York she had enjoyed conspicuous success as a composer, music critic, concert organiser and radio commentator, job security was an unachievable dream and she was often in debt. Moreover, the performance of her opera The Transposed Heads in 1958 had been poorly reviewed and the schadenfreude of critics and rival composers ineradicably poisoned her association with them. In Greece, she settled in Athens and began writing an opera. In the meantime, she explored the islands and bought a derelict dovecot on Mykonos.

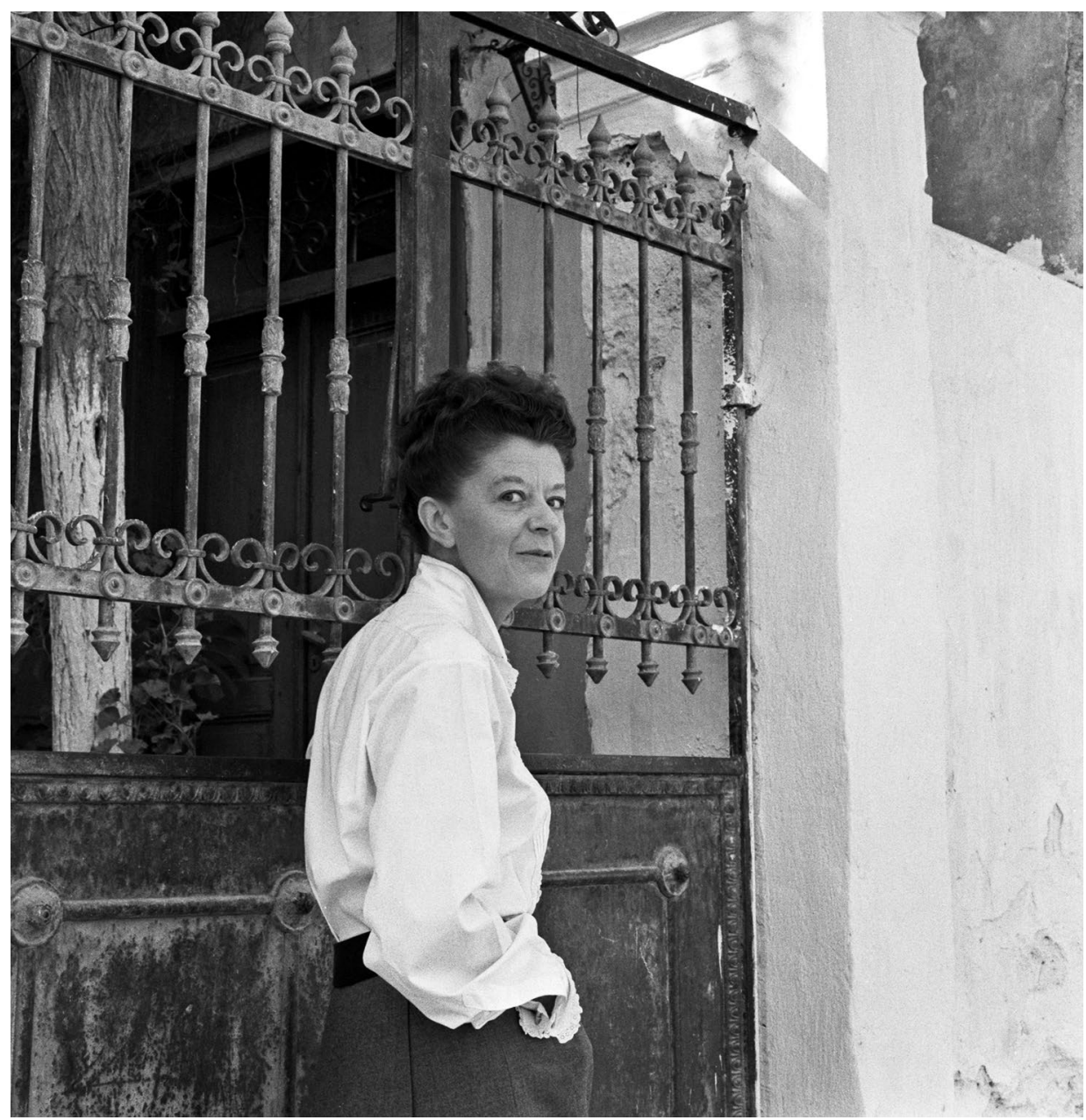

Figure 1 Glanville-Hicks in Athens, c. 1960. Portrait by Roloff Beny

Source: Library and Archives Canada/Credit: Roloff Beny/Roloff Beny fonds/E011201139. @) Library and Archives Canada. Reproduced with the permission of Library and Archives Canada. 
There are a number of reasons why, of the 36 islands she visited, Mykonos was the most attractive. First, her Hicks ancestors had lived for centuries on the Isles of Scilly near Cornwall, which are known for their pristine white sands, subtropical climate and ancient stone relics. Scillonians, like Mykoniots, were legendary sailors and adventurers. A small statue in the square near Mykonos harbour celebrates the feats of the revolutionary heroine Mantó Mavrogénous (1796-1848), a wealthy and beautiful aristocrat and cosmopolitan who led a repulse of Turkish forces in the War of Independence in 1821. Glanville-Hicks's first and closest friend on the island was Vienoúla Kousathana, an English-speaking craftswoman in her fifties who had founded a weaving cooperative that employed islander women in creating fabrics of kaleidoscopic colours and textures that enchanted visitors. Glanville-Hicks herself, writing about the island in American Vogue a few years later, described Kousathana as

the black-eyed, white-haired English-speaking, and witty matriarch figure who has played a major role in making Mykonos famous as a weaver's island, and her subtle use of textures and colors sets her apart from all others. She is a Homeric figure on a Homeric landscape, and on dyeing days, her garden with its potions of shocking pink, moss green, orange, and purple bubbling in copper cauldrons identical with those from the Cretan excavations, might well be a scene from a Knossos fresco. ${ }^{58}$

Glanville-Hicks's house sat in a rocky niche on the hillside overlooking the hora (the main town) and was a whitewashed box with a turreted roof in front of a rockscape covered in spring with blue and yellow flowers. The purchase was arranged at a ceremony attended by representatives of the five families that had traded the house as part of their daughters' dowries-fishermen, shepherds, boatmen and the ruling aristocrats among them. At another ceremony, a water diviner cut a forked branch from an olive tree and, after waving the stick over the land, announced where a well should be dug.

Vienoúla Kousathana's nephew Michalis Lykos agreed to oversee the renovations of the dovecot. Having been promised that she would be treated as an 'island girl' and so charged 'island prices', Glanville-Hicks became an employer and project manager, commissioning new doors and windows, a terrace, a well, toilet tank, kitchen and 'luxury' bathroom. For the most part, the workmen used traditional methods. They collected bags of fikia seaweed and mud for insulation and fetched the gravel for the plaster walls from a nearby beach, transporting it back to the house on donkeys. It was Glanville-Hicks's intention that it should be 'a handmade house made with material close at hand and with techniques millenniums old', but as a good modernist she installed electricity for the kitchen and bathroom and an electric pump for the well. ${ }^{59}$ Her fantasy of creating something wholly traditional with ancient methods was encouraged by Lykos himself, a humble tradesman and shepherd who was the

58 Glanville-Hicks, 'My Beautiful Greek House-Handmade for \$2,000', Vogue 141 (1 April 1963): 35.

59 Glanville-Hicks, 'My Beautiful Greek House', 52. 
strongest man on the island, the best dancer, a capable musician and a natural leader. Inevitably, Glanville-Hicks fell in love with him. He was described by a visitor as 'a fine-looking man, with wide, strong hands, a wide, strong, craggy face, and a dome of a head above it'. ${ }^{60}$ When the house was finished, the new owner praised Lykos as a fellow artist, proud that his signature was scored into the cement work as though he was a painter signing a masterpiece. No-one is sure whether there was in fact an affair; according to Beckett, Lykos had a reputation as a 'Don Juan', offering companionship to women in need, and yet one of Peggy's friends told me it was unlikely she would have stooped to an affair with a Greek. ${ }^{61}$ That comment implies that there were racial and class differences in play, and that Glanville-Hicks was exploiting racial difference for the sake of personal opportunity.

If on the one hand she exhibited a desire to recover lost origins - what Simon Gikandi calls 'self-realization in the spaces of the other'-her very presence is recognisable as 'a project of power and control, of domination and racial exclusiveness that ... provided the context in which modern identities were constituted' ${ }^{62}$ In selecting and renovating a house on an island noted for its spectacular scenery and architecture, Glanville-Hicks was performing her modernity, simultaneously searching in a remote and as yet untrampled place for lost origins - in ancient traditions of weaving, building and seafaring, in the island's proximity to Delos, in reliance even in the 1960s on hurricane lamps and donkeys and in enjoying primitive-sounding tsambouna music - while composing an opera in a modern language, writing an article destined for the New York edition of Vogue and corresponding with members of an artistic avant-garde. To several of them, she described her life in a 'blue and white island paradise'. ${ }^{63}$ On her advice, Yehudi Menuhin and his wife, Diana, also bought a house on Mykonos. As Menuhin described in his autobiography, he and Diana

respected the simplicity of our little peasant house. Built of stone, the roof insulated with straw and seaweed between narrow beams (for wood is precious on the island), with a distinctive little chimney, it is cool, white, clean and totally unspoiled. For a few years it was an idyllic summer holiday hermitage where one wore one's oldest clothes, swam in the empty sea, daily collected steaming loaves of black bread from the baker's brushwood oven, and took evening walks in what Diana called our supermarket-our three terraces and the adjoining vineyard where grapes, figs, pomegranates, prickly pears, tomatoes and quinces grew, these last usually full of worms. ${ }^{64}$

60 Christopher Rand, Grecian Calendar (New York: Oxford University Press, 1962), 121.

61 Beckett, Peggy Glanville-Hicks, 169.

62 Simon Gikandi, Maps of Englishness: Writing Identity in the Culture of Colonialism (New York: Columbia University Press, 1996), 9.

63 Quoted in Robinson, Peggy Glanville-Hicks, 205.

64 Yehudi Menuhin, Unfinished Journey: Twenty Years Later (New York: Fromm International Publishing Corporation, 1999), 209. 
When Glanville-Hicks's house was completed, she chose the date of a full moon to move in and at sunrise took a caique to Delos and climbed Mount Kynthos to give thanks to Apollo.

Coincidentally, the opera she was composing was based on Lawrence Durrell's play about the life of the poet Sappho. By selecting his play, Glanville-Hicks secured a connection to a leading British novelist and, more usefully, to the writer known for his atmospheric memoirs of life on the islands of Corfu, Rhodes and Cyprus. ${ }^{65}$ In January 1963, Durrell wrote to Glanville-Hicks to say that the prospect of a Sappho opera was almost too good to be true. She began work on 1 March, ecstatic to have found a foremother whose life experience as a woman and creator resonated deeply with her own. Of his many female characters, Glanville-Hicks wrote to Durrell, Sappho was one of the most intriguing, 'so exactly the kind of woman it must have been who wrote those ecstatically frugal lines'. ${ }^{66}$ In early June, Durrell and his wife, Claude, visited Glanville-Hicks on Mykonos. They discussed the opera but otherwise spent five days in an inebriated haze, carousing at her piano by night and going on picnics and expeditions to Delos by day. ${ }^{67}$ She had, in fact, renewed Durrell's love of Mykonos. He was to write in his book on the Greek Islands of the 'extraordinary cubist village, with its flittering, dancing shadows, and its flaring nightmare of whiteness', of the souk brimming with carpets, brocades, blankets and shawls, of the 'voluptuous shapes of breasts translated into cupolas and apses, into squinches and dovecots' and above all of the island's 'eye-caressing beauty' ${ }^{68} \mathrm{He}$ also wrote of a clandestine (and illegal) overnight stay on the island of Delos, an escapade that Peggy, with her reverence for Apollo, probably engaged in herself. ${ }^{69}$

Just as she achieved her personal nirvana, however, Glanville-Hicks's paradise soured when the reality of her poverty prevented her acquiring more land, and when encroaching tourism threatened to spoil the serenity of her hideaway. Soon after she moved in, she was visited by two men in business suits who wanted to know what she had paid for her property. This worried her for two reasons, because it might be found that she had failed to pay enough tax on her land and because the knowledge of a figure as famous as Yehudi Menuhin buying property would inevitably jack up prices, when she hoped to purchase the land surrounding her house. The chief culprit, in her view, was Jim Price, the American Menuhin had employed as his agent on the island. Price was a friend of Glanville-Hicks_-it is possible they had an affair a few years earlier in New York-but she now waged a campaign to have him drummed

65 Lawrence Durrell, Prospero's Cell: A Guide to the Landscape and Manners of the Island of Corcyra [Corfu] (London: Faber \& Faber, 1945); Lawrence Durrell, Reflections on a Marine Venus (London: Faber \& Faber, 1953); Lawrence Durrell, Bitter Lemons (London: Faber \& Faber, 1957).

66 Glanville-Hicks, letter to Lawrence Durrell, 2 March 1963, quoted in Robinson, Peggy Glanville-Hicks, 210.

67 It is unclear in her diary how long Durrell was on Mykonos, but it was most likely five days, from 10 June to

15 June. See diary for 1963, Series 3, PGH-NLA.

68 Lawrence Durrell, The Greek Islands (London: Faber, 1978), 228, 231.

69 In describing the overnight visit to Delos, Durrell dated it to 1966 and reported that his wife had recently had an operation. But the operation took place in 1963, shortly before his visit to Glanville-Hicks on Mykonos. See Ian S. Macniven, Lawrence Durrell: A Biography (London: Faber, 1998), 533. Claude Durrell died on 1 January 1967. 
off the island. Menuhin was horrified, and even more aghast when he received letters from Glanville-Hicks describing Price as a warlock. ${ }^{70} \mathrm{He}$ was appalled that she could accuse her former friend of 'mania, insanity, sadism, violence-particularly at full moon, etc. ${ }^{71}$ However it was engineered, Price subsequently left the island and the Menuhins no longer corresponded with Glanville-Hicks as regularly as before. ${ }^{72}$ Two years later, fearful that Mykonos would be ruined by tourism, Glanville-Hicks bought a shell of a house on the nearby island of Tinos and proceeded to employ Tyniots in renovating it. The Mykonos house eventually sold for a handsome sum. ${ }^{73}$

A decade later when Durrell came to write his book about the Greek Islands, he referred to Mykonos as a 'choice and secret place' and to its Athenian habitués as a 'little club of Mykoniots d'election' ${ }^{74}$ In her anthropological study of this exclusive group as it coalesced in the 1970s and afterwards, Pola Bousiou describes its members as nomads and "mystic" participants in an ideal socialisation' who occupy an artificial and yet ideal space. ${ }^{75}$ Subject to a romanticised 'tourist gaze', the island renowned for its vernacular architecture and craftsmanship became in subsequent decades an object of elite consumption. ${ }^{76}$ The perpetual reconstitution of the town's quintessentially traditional yet modern Greek Island-style architecture 'faked' or 'staged' its authenticity. ${ }^{77}$ Visitors came not just to admire or photograph the landscape but, like Glanville-Hicks, also to literally possess it. Although there are today modern Greek houses planted on the fringes of the town, there are also dovecots renovated as lovingly as Glanville-Hicks's and the vista the visitor sees from the ferry is still a jumble of whitewashed boxes. Glanville-Hicks unquestionably subscribed to the island's myth of exclusivity, becoming in her own words an 'aristocrat'-reserving her house for a privileged group of New York artists she described as 'family'. ${ }^{78}$ In my view, her shameless behaviour when her tranquillity was threatened was less the product of work-related stress or illness, as one of her previous biographers speculates, ${ }^{79}$ than a violent reaction to the attack on the performative identity she had created for herself in the wake of years of hardship and bitterness in New York. For the remainder of her life, she was to pursue the chimera of this identity, performed most clearly in the portrait from 1989 showing

\footnotetext{
70 Murdoch, Peggy Glanville-Hicks, 192.

71 Yehudi Menuhin, letter to Glanville-Hicks, 5 August 1963, quoted in Robinson, Peggy Glanville-Hicks, 211.

72 There is a gap in the extant correspondence between Glanville-Hicks and the Menuhins from 1963 to 1966 and very few letters beyond that date. The correspondence is held in Box 2, PGH-SLNSW, and in the Menuhin archive at the Royal Academy of Music in London.

73 See Glanville-Hicks, letter to Ian Potter, 3 March 1971, Box 4, PGH-SLNSW.

74 Durrell, The Greek Islands, 236.

75 Pola Bousiou, The Nomads of Mykonos: Performing Liminalities in a 'Queer' Space (New York: Berghahn Books, 2008), 3.

76 John Urry, The Tourist Gaze, 2nd edn (London: Sage, 2002), 4.

77 Bousiou, Nomads of Mykonos, 14.

78 See, for example, Beckett, Peggy Glanville-Hicks, 196; and Glanville-Hicks's letter to the Brazilian journalist and musicologist Luiz Heitor Corrêa de Azevedo, dated 17 September 1948, in which she refers to 'aristocrats' who uphold truth and enlightenment (Box 14, PGH-SLNSW).

79 Murdoch, Peggy Glanville-Hicks, 192.
} 
her in a red cloak holding an owl, a symbol of Athens. ${ }^{80}$ Displayed on the wall next to her are two of her own ancient Greek masks, further signifying her association with Greece and its history. The cloak hides her figure, its shapelessness disguising her age and the painting's date. Rather than appearing as an old lady from Sydney, she inhabits a timeless and mythical space, with a look of hauteur to match.

\section{Heroine or anti-heroine?}

Knowing this much, or at least applying twenty-first-century investigative tools to a mid-twentieth-century life, makes it impossible to construct a biographical identity of Glanville-Hicks as a heroine in the tradition of Carlyle's paragons. To do so would be to overlook aspects of her life and personality for which we have ample documentation. It would also require privileging the public over the private. This would have suited Glanville-Hicks; perhaps she knew that the hundreds of letters she hoarded for posterity would one day be read very closely and only rarely in a letter did she deviate from artistic or professional matters. Although many of her claims cannot be taken for granted, the memories and letters of friends, colleagues and even enemies provide counterpoints that help to place her in historical context. One of the most precious of these countervailing sources, and the one that catches her off guard at moments of her greatest vulnerability, is the diary of the feminist author Anaïs Nin. One day Glanville-Hicks described for Nin the habits of the lapwing bird, which erases its tracks by sweeping the sand with its wings. Nin appreciated the story's metaphor, knowing that both of them were hiding deeply rooted secrets. ${ }^{81}$ GlanvilleHicks destroyed her most intimate correspondence, with her mother, her best friend and with lovers she preferred to forget. But enough remains to be able to sense the very private psychological journey she underwent. To my mind, Glanville-Hicks's accomplishment does not rest on her career highlights, the firsts she achieved or her friendship with Great Men. It lies in the challenges she set for herself, her capacity to envisage new paths and her ability to respond imaginatively to creative impulses.

This is not to say that I am willing to suspend judgement, but to acknowledge that the value of the life might lie in unexpected places. I am encouraged by Carlyle, who, when writing of Dante, pinpointed the essential quality required to attend to the whole person:

Find a man whose words paint you a likeness, you have found a man worth something; mark his manner of doing it, as very characteristic of him. In the first place, he could not have discerned the object at all, or seen the vital type of it, unless he had, what we may call, sympathized with it—had sympathy in him to bestow on objects. ${ }^{82}$

80 See the portrait at: pghcomposercritic.tumblr.com/.

81 Anaïs Nin, diary entry for 16 February 1956, Anaïs Nin Papers, University of California, Los Angeles.

82 Carlyle, 'The Hero as Poet', in On Heroes, Hero-Worship and the Heroic in History. See also Hermione Lee, 'Introduction: Writing about Lives', in Body Parts: Essays in Life-Writing (London: Chatto \& Windus, 2005), 1-2. 
Sympathy came naturally to Virginia Woolf, who, in A Room of One's Own, found herself imagining the life of an ancient lady she saw crossing the street on the arm of a middle-aged woman. If, she mused,

one asked her what her life has meant to her, she would say that she remembered the streets lit for the battle of Balaclava, or had heard the guns fire in Hyde Park for the birth of King Edward the Seventh ... [but that nothing remained of] all the dinners cooked; the plates and cups washed, the children sent to school and gone out into the world..$^{83}$

And then she thought of the girl behind the counter and declared: 'I would as soon have her true history as the hundred and fiftieth life of Napoleon or seventieth study of Keats and his use of Miltonic inversion.' ${ }^{84}$ Woolf appreciates not only the sanctity of small lives, but also her own appetite for life-writing itself. No biographical subject—and certainly no woman — needs to be a saint or a war hero for someone to appreciate them. In Johnson's words, 'there has rarely passed a life of which a judicious and faithful narrative would not be useful'. ${ }^{85}$ GlanvilleHicks might not (yet) be remembered by a blue plaque on the worker's cottage in St Kilda where she was born, and there is no chair with a label that says it was the one in which she sat while composing, but it is not the biographer's mission to prove her worthy of such things.

Nor, then, do her biographers need to shy away from reporting her views and actions. Another of the axioms of modern biography is that neither 'truth' nor the 'inner truth' can be fully known or inferred. According to Liz Stanley, the past 'is a mythology created out of scraps and traces and partial interpretations-those from the past as well as those of the historian-auto/biographer' ${ }^{86}$ What records we have show that Glanville-Hicks could be nasty, spiteful, vindictive, hypocritical and dishonest, but in discovering that, my task as a biographer was to present her complexities, contradictions and multiple selves, and to situate rather than to exonerate her. My version is surely as subjective as any other, but I would rather present the life in all its chromatic intensity than sidestep the flaws like puddles on the street. 'If we owe regard to the memory of the dead', Johnson wrote, 'there is yet more respect to be paid to knowledge, to virtue, and to truth' ${ }^{87}$

83 Virginia Woolf, A Room of One's Own/Three Guineas, ed. Morag Shiach (Oxford: Oxford University Press, 1992), 116.

84 Woolf, A Room of One's Own, 118.

85 Samuel Johnson, 'The Dignity and Usefulness of Biography' (1750), www.johnsonessays.com/the-rambler/ dignity-usefulness-biography/.

86 Liz Stanley, The Auto/Biographical I: The Theory and Practice of Feminist Auto/Biography (Manchester: Manchester University Press, 1992), 86.

87 Johnson, 'The Dignity and Usefulness of Biography'. 
This text is taken from Australian Journal of Biography and History: No. 3, 2020, published 2020 by ANU Press, The Australian National University, Canberra, Australia.

doi.org/10.22459/AJBH.2020.02 